for conservation globally

Threatened

通
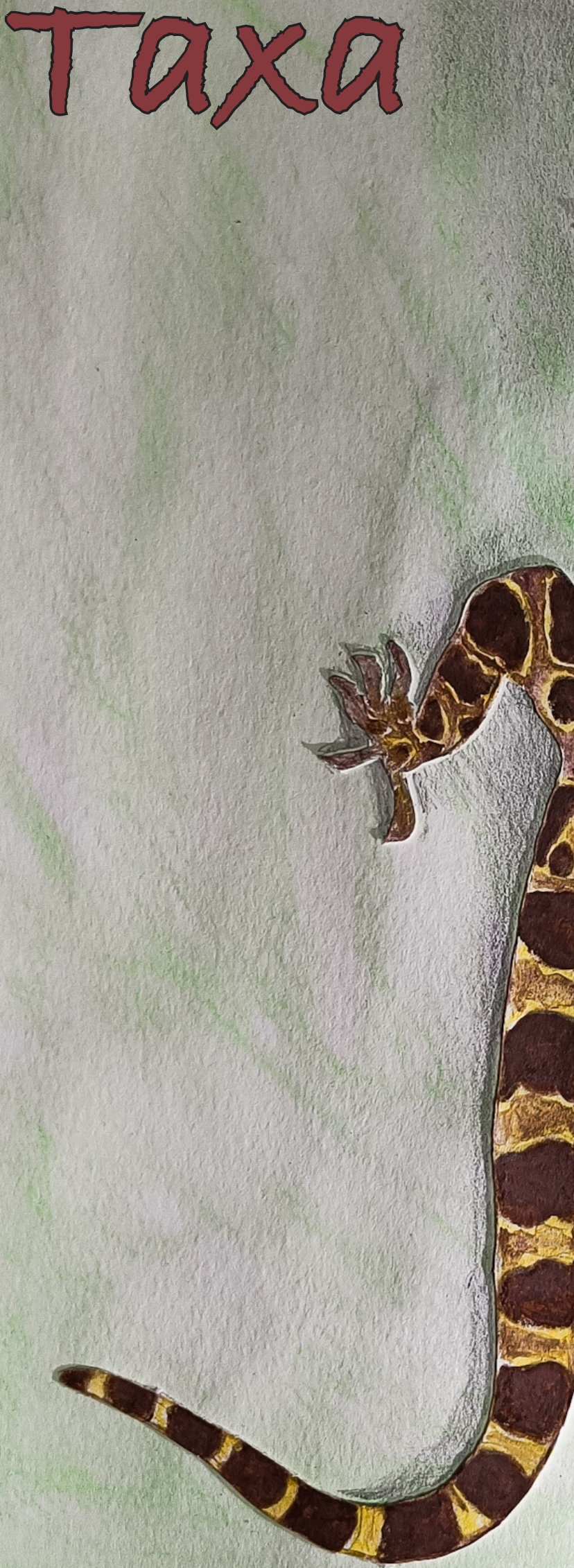

Open Access

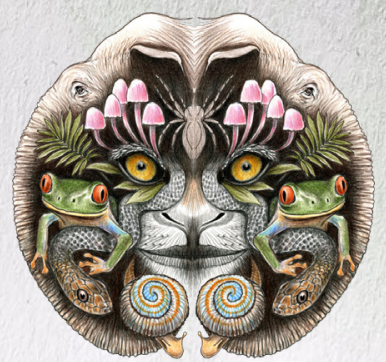

$10.1160 \mathrm{~g} / \mathrm{j}$ ott.2022.14.1.20311-20538 wWw.threatenedtaxa.org

26 January 2022 (Online \& Print) 14(1): 20311-20538 ISSN0974-7907 (Online) ISSN 0974-7893 (Print) 


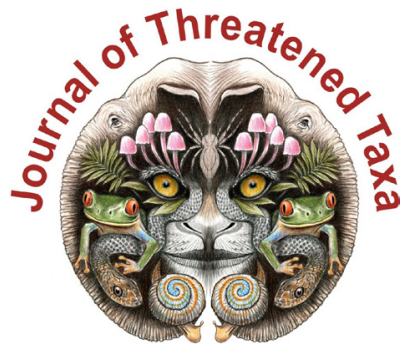

ISSN 0974-7907 (Online); ISSN $0974-7893$ (Print)

Publisher

Host

Wildlife Information Liaison Development Society

www.wild.zooreach.org

Zoo Outreach Organization www.zooreach.org

No. 12, Thiruvannamalai Nagar, Saravanampatti - Kalapatti Road, Saravanampatti, Coimbatore, Tamil Nadu 641035, India

Ph: +91 9385339863 | www.threatenedtaxa.org

Email: sanjay@threatenedtaxa.org

EDITORS

\section{Founder \& Chief Editor}

Dr. Sanjay Molur

Wildlife Information Liaison Development (WILD) Society \& Zoo Outreach Organization (ZOO),

12 Thiruvannamalai Nagar, Saravanampatti, Coimbatore, Tamil Nadu 641035, India

\section{Deputy Chief Editor}

Dr. Neelesh Dahanukar

Noida, Uttar Pradesh, India

\section{Managing Editor}

Mr. B. Ravichandran, WILD/ZOO, Coimbatore, India

\section{Associate Editors}

Dr. Mandar Paingankar, Government Science College Gadchiroli, Maharashtra 442605, India

Dr. Ulrike Streicher, Wildlife Veterinarian, Eugene, Oregon, USA

Ms. Priyanka Iyer, ZOO/WILD, Coimbatore, Tamil Nadu 641035, India

Dr. B.A. Daniel, ZOO/WILD, Coimbatore, Tamil Nadu 641035, India

\section{Editorial Board}

Dr. Russel Mittermeier

Executive Vice Chair, Conservation International, Arlington, Virginia 22202, USA

\section{Prof. Mewa Singh Ph.D., FASc, FNA, FNASc, FNAPsy}

Ramanna Fellow and Life-Long Distinguished Professor, Biopsychology Laboratory, and Institute of Excellence, University of Mysore, Mysuru, Karnataka 570006, India; Honorary Professor, Jawaharlal Nehru Centre for Advanced Scientific Research, Bangalore; and Adjunct Professor, National Institute of Advanced Studies, Bangalore

\section{Stephen D. Nash}

Scientific Illustrator, Conservation International, Dept. of Anatomical Sciences, Health Sciences Center, T-8, Room 045, Stony Brook University, Stony Brook, NY 11794-8081, USA

\section{Dr. Fred Pluthero}

Toronto, Canada

\section{Dr. Priya Davidar}

Sigur Nature Trust, Chadapatti, Mavinhalla PO, Nilgiris, Tamil Nadu 643223, India

\section{Dr. Martin Fisher}

Senior Associate Professor, Battcock Centre for Experimental Astrophysics, Cavendish

Laboratory, JJ Thomson Avenue, Cambridge CB3 OHE, UK

\section{Dr. John Fellowes}

Honorary Assistant Professor, The Kadoorie Institute, 8/F, T.T. Tsui Building, The University of Hong Kong, Pokfulam Road, Hong Kong

\section{Prof. Dr. Mirco Solé}

Universidade Estadual de Santa Cruz, Departamento de Ciências Biológicas, Vice-coordenado do Programa de Pós-Graduação em Zoologia, Rodovia Ilhéus/Itabuna, Km 16 (45662-000)

Salobrinho, Ilhéus - Bahia - Brasil

\section{Dr. Rajeev Raghavan}

Professor of Taxonomy, Kerala University of Fisheries \& Ocean Studies, Kochi, Kerala, India

\section{English Editors}

Mrs. Mira Bhojwani, Pune, India

Dr. Fred Pluthero, Toronto, Canad

Mr. P. Ilangovan, Chennai, India

Web Development

Mrs. Latha G. Ravikumar, ZOO/WILD, Coimbatore, India

\section{Typesetting}

Mr. Arul Jagadish, ZOO, Coimbatore, India

Mrs. Radhika, ZOO, Coimbatore, India

Mrs. Geetha, ZOO, Coimbatore India
Fundraising/Communications

Mrs. Payal B. Molur, Coimbatore, India

Subject Editors 2018-2020

Fungi

Dr. B. Shivaraju, Bengaluru, Karnataka, India

Dr. R.K. Verma, Tropical Forest Research Institute, Jabalpur, India

Dr. Vatsavaya S. Raju, Kakatiay University, Warangal, Andhra Pradesh, India

Dr. M. Krishnappa, Jnana Sahyadri, Kuvempu University, Shimoga, Karnataka, India

Dr. K.R. Sridhar, Mangalore University, Mangalagangotri, Mangalore, Karnataka, India

Dr. Gunjan Biswas, Vidyasagar University, Midnapore, West Bengal, India

\section{Plants}

Dr. G.P. Sinha, Botanical Survey of India, Allahabad, India

Dr. N.P. Balakrishnan, Ret. Joint Director, BSI, Coimbatore, India

Dr. Shonil Bhagwat, Open University and University of Oxford, UK

Prof. D.J. Bhat, Retd. Professor, Goa University, Goa, India

Dr. Ferdinando Boero, Università del Salento, Lecce, Italy

Dr. Dale R. Calder, Royal Ontaro Museum, Toronto, Ontario, Canada

Dr. Cleofas Cervancia, Univ. of Philippines Los Baños College Laguna, Philippines

Dr. F.B. Vincent Florens, University of Mauritius, Mauritius

Dr. Merlin Franco, Curtin University, Malaysia

Dr. V. Irudayaraj, St. Xavier's College, Palayamkottai, Tamil Nadu, India

Dr. B.S. Kholia, Botanical Survey of India, Gangtok, Sikkim, India

Dr. Pankaj Kumar, Kadoorie Farm and Botanic Garden Corporation, Hong Kong S.A.R., China

Dr. V. Sampath Kumar, Botanical Survey of India, Howrah, West Bengal, India

Dr. A.J. Solomon Raju, Andhra University, Visakhapatnam, India

Dr. Vijayasankar Raman, University of Mississippi, USA

Dr. B. Ravi Prasad Rao, Sri Krishnadevaraya University, Anantpur, India

Dr. K. Ravikumar, FRLHT, Bengaluru, Karnataka, India

Dr. Aparna Watve, Pune, Maharashtra, India

Dr. Qiang Liu, Xishuangbanna Tropical Botanical Garden, Yunnan, China

Dr. Noor Azhar Mohamed Shazili, Universiti Malaysia Terengganu, Kuala Terengganu, Malaysia

Dr. M.K. Vasudeva Rao, Shiv Ranjani Housing Society, Pune, Maharashtra, India

Prof. A.J. Solomon Raju, Andhra University, Visakhapatnam, India

Dr. Mandar Datar, Agharkar Research Institute, Pune, Maharashtra, India

Dr. M.K. Janarthanam, Goa University, Goa, India

Dr. K. Karthigeyan, Botanical Survey of India, India

Dr. Errol Vela, University of Montpellier, Montpellier, France

Dr. P. Lakshminarasimhan, Botanical Survey of India, Howrah, India

Dr. Larry R. Noblick, Montgomery Botanical Center, Miami, USA

Dr. K. Haridasan, Pallavur, Palakkad District, Kerala, India

Dr. Analinda Manila-Fajard, University of the Philippines Los Banos, Laguna, Philippines

Dr. P.A. Sinu, Central University of Kerala, Kasaragod, Kerala, India

Dr. Afroz Alam, Banasthali Vidyapith (accredited A grade by NAAC), Rajasthan, India

Dr. K.P. Rajesh, Zamorin's Guruvayurappan College, GA College PO, Kozhikode, Kerala, India

Dr. David E. Boufford, Harvard University Herbaria, Cambridge, MA 02138-2020, USA

Dr. Ritesh Kumar Choudhary, Agharkar Research Institute, Pune, Maharashtra, India

Dr. Navendu Page, Wildlife Institute of India, Chandrabani, Dehradun, Uttarakhand, India

\section{Invertebrates}

Dr. R.K. Avasthi, Rohtak University, Haryana, India

Dr. D.B. Bastawade, Maharashtra, India

Dr. Partha Pratim Bhattacharjee, Tripura University, Suryamaninagar, India

Dr. Kailash Chandra, Zoological Survey of India, Jabalpur, Madhya Pradesh, India

Dr. Ansie Dippenaar-Schoeman, University of Pretoria, Queenswood, South Africa

Dr. Rory Dow, National Museum of natural History Naturalis, The Netherlands

Dr. Brian Fisher, California Academy of Sciences, USA

Dr. Richard Gallon, llandudno, North Wales, LL30 1UP

Dr. Hemant V. Ghate, Modern College, Pune, India

Dr. M. Monwar Hossain, Jahangirnagar University, Dhaka, Bangladesh

Mr. Jatishwor Singh Irungbam, Biology Centre CAS, Branišovská, Czech Republic.

Dr. Ian J. Kitching, Natural History Museum, Cromwell Road, UK

Dr. George Mathew, Kerala Forest Research Institute, Peechi, India

For Focus, Scope, Aims, and Policies, visit https://threatenedtaxa.org/index.php/JoTT/aims_scope
For Article Submission Guidelines, visit https://threatenedtaxa.org/index.php/JoTT/about/submissions
For Policies against Scientific Misconduct, visit https://threatenedtaxa.org/index.php/JoTT/policies_various

continued on the back inside cover 
Journal of Threatened Taxa | www.threatenedtaxa.org | 26 January 2022 | 14 (1):20526-20529

ISSN0974-7907 (Online) | ISSN0974-7893 (Print)

\title{
Ipomoea laxiflora H.J. Chowdhery \& Debta (Convolvulaceae): new records for the Western Ghats and semiarid regions
}

\author{
Sachin M. Patil ${ }^{1}$ (D) Ajit M. Vasava ${ }^{2}$ (D), Vinay M. Raole ${ }^{3}$ (D) \& Kishore S. Rajput ${ }^{4}$ (D)
}

\begin{abstract}
${ }^{1}$ Department of Botany, Shivaji University, Kolhapur, Maharashtra 416004, India.
${ }^{2-4}$ Department of Botany, Faculty of Science, The Maharaja Sayajirao University of Baroda, Vadodara, Gujarat 390002, India.

${ }^{1}$ sach2010d@gmail.com, ${ }^{2}$ ajitvsv@gmail.com, ${ }^{3}$ vinaysar@reddifmail.com, ${ }^{4}$ ks.rajput15@yahoo.com (corresponding author)
\end{abstract}

Ipomoea $\mathrm{L}$. is one of the largest genera of the family Convolvulaceae Juss., growing naturally in tropical, subtropical, and temperate regions (Kattee et al. 2019). Members of the family are characterised by their twining and trailing herbaceous or perennial habit, whereas shrubs or trees are rare. About 650 species are reported worldwide in Convolvulaceae (Mabberley 2017); of which 64 species are reported from different biogeographical regions of India (Shimpale et al. 2014; Kattee et al. 2019). Many of them have been used as ornamental plants with a popular English name 'morning glory', in foods, medicines, and in religious rituals (Meira et al. 2012). During field trips to different regions of Gujarat state for collection of Ipomoea and other species of the Convolvulaceae for histological studies, the authors collected a few specimens of Ipomoea (looking similar to I. triloba) with glabrous fruits. After studying the literature (Chowdhery \& Debta 2009; Singh et al. 2011; Kattee et al. 2019) and comparing with the herbarium specimens deposited in The New College Herbarium \& Shivaji University Kolhapur (SUK) Herbarium, the collected specimens were identified as I. laxiflora H.J.Chowdhery \& Debta. I. laxiflora is known from northern India (Uttarakhand) and recently reported from Deccan peninsula (eastern region of Kolhapur district) by Kattee et al. (2019). It has not been reported from the Western Ghats (including the Kolhapur district), however, now it is collected from the Dangs (Western Ghats region of Gujarat) and semiarid regions of Gujarat. Herewith, the species is reported as a new distribution record for the Western Ghats and semiarid region of India. The presence of this species in these regions will help researchers working in the area to understand the distribution pattern of this endemic species. This discovery also hints towards its possible wider distribution range. A detailed description, distribution conservation status, and photographs (Image 1) of I. laxiflora are provided herewith.

Ipomoea laxiflora H.J.Chowdhery \& Debta, Indian J. Forest. 2009, 32(1): 120-121 (Image 1)

Plants 4-5 m (6 m) long, annual climber; stems purple-green, soft, herbaceous, quadrangular, sparsely hairy at nodes; leaves 5-10 × 4-9 cm, simple, showing great variations in shape, cordate or trilobed, acuminate, entire, base cordate; petioles 7-12 cm, purple-green, long, glabrous; flowers 3-7 in lax cymes, monoecious, clumped; peduncles 5-8 cm long, purple-green, slightly verrucose, glabrous, swollen at apex; pedicels $2.5-3 \mathrm{~mm}$ long, quadrangular, glabrous, elongated in fruits; bracts

Copyright: (c) Patil et al. 2022. Creative Commons Attribution 4.0 International License. JoTT allows unrestricted use, reproduction, and distribution of this article in any medium by providing adequate credit to the author(s) and the source of publication.

Funding: No funds received to carry present work. 

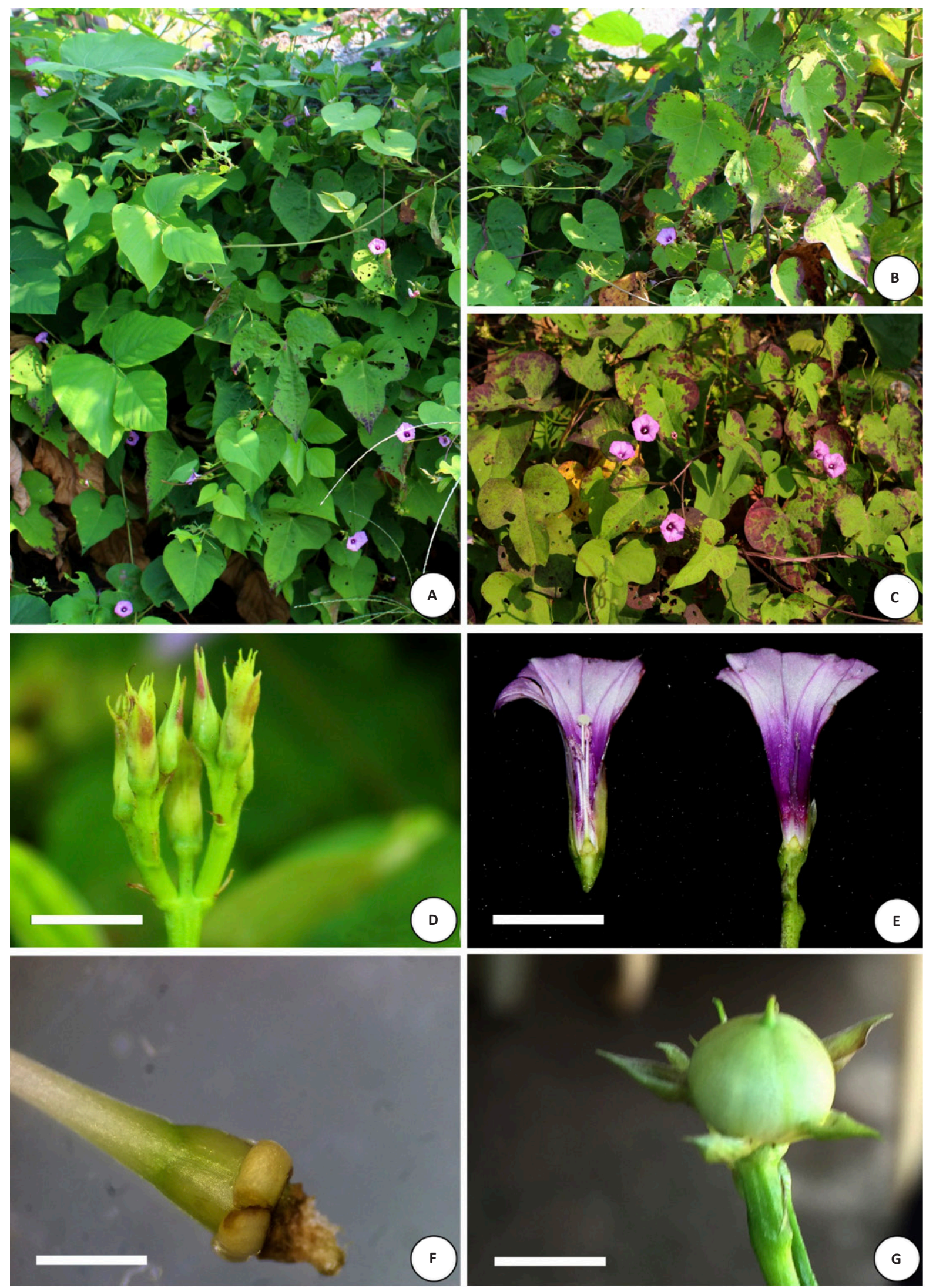

Image 1. Ipomoea laxiflora: A-C-Habit | D-Young floral buds | E-Flowers (longitudinal section of flower on the left and complete flower on the right) | F-Gynoecium, | G-Fruits (note the absence of hairs on gynoecium and capsule). Scale: D \& E = 1cm | F = 2cm | G = 5mm. (c) K.S. Rajput and S.M. Patil 


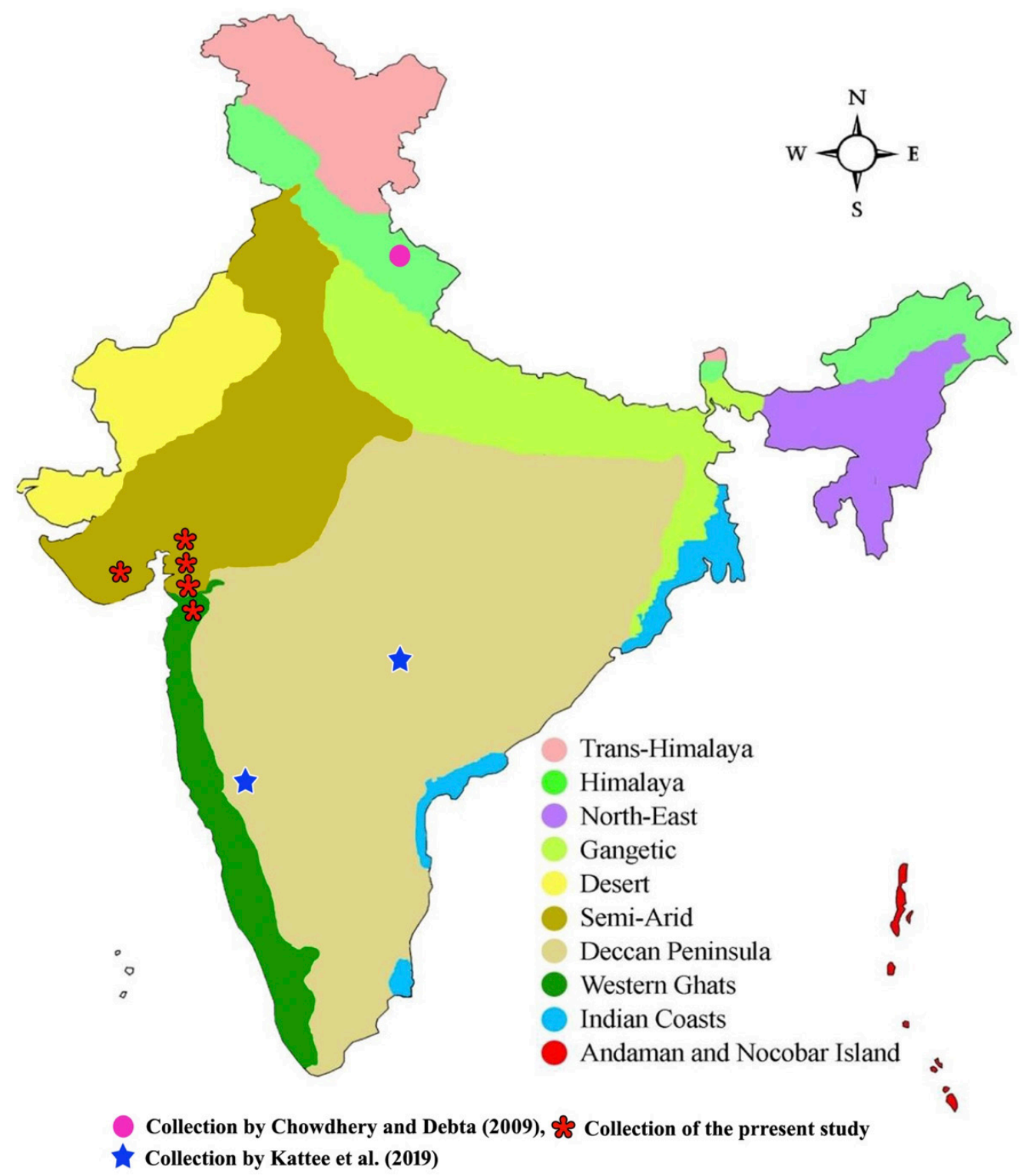

Figure 1. Point locations of Ipomoea laxiflora (marked with dots) in different biogeographic zones of India (map not to scale).

2-4 mm long, linear, caducous; calyx 5, fused, green with purple tinged at tip; lobes $0.7-0.9 \times 0.2-0.3 \mathrm{~cm}$, ovate-lanceolata, sub-equal, feebly veined, glabrous; corolla c. $1.5 \times 1.2 \mathrm{~cm}$, funnel-shaped; limb 5-lobed; lobes apiculate; stamens 5; filaments $0.7-0.8 \mathrm{~cm}$ long, unequal, included, hairy at base; ovary c. $1 \times 1.5 \mathrm{~mm}$, glabrous; style c. $0.6-1 \mathrm{~cm}$ long; stigma unlobed or bilobed; capsules ovoid, $5 \times 6 \mathrm{~mm}$, 4-valved, with purple tinge at young, glabrous; seeds 4 per capsule, ovoid to deltoid, brownish-black, c. $4 \times 4 \mathrm{~mm}$, glabrous.

Flowering period: September-October

Distribution: India

Note: In India this was reported from Uttarakhand and Maharashtra. However, now it is collected from the Western Ghats (The Dangs) and semi-arid regions (Vadodara, Panchmahal, and Rajkot) of Gujarat state (Figure 1).

Conservation status: Ipomoea laxiflora is an endemic species collected from different regions of India (Singh et al. 2015). In the present work it has been collected from the Western Ghats and semiarid regions of India. About 30-80 individuals were found per locality and the area of occupancy (AOO) is $150-250 \mathrm{~km}^{2}$ by using the Geo-CAT software. However, other forest regions are yet to be explored completely and the species may be distributed under similar ecological conditions. Hence, more floristic surveys are needed to determine and document the full range of distribution of Ipomoea 


\section{laxiflora.}

Ecology: The species grows from high rainfall regions $(>1,300 \mathrm{~mm})$ to low rainfall $(<400 \mathrm{~mm})$ regions. It grows on sandy gravelly or sandy alluvial soil on hilly terrain, foot hills and hill slopes. It also occurs in human habitats particularly on farm or home fencing and compound walls of industries, along road sides and in open areas. The phyto-associates observed in various areas are Capparis decidua (Forssk.) Edgew., Euphorbia sp., Ficus hispida L.f., Pongamia pinnata (L.) Pierre, Prosopis juliflora (Sw.) DC., P. cineraria (L.) Druce, and Ziziphus sp. Specimens examined: 1001 (BARO!) 2019, Gujarat, Dangs forest $\left(20^{\circ} 45^{\prime} 38^{\prime \prime} \mathrm{N} \& 73^{\circ} 41^{\prime} 54^{\prime \prime} \mathrm{E}\right)$, coll. Patil,

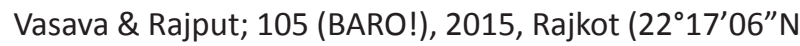
\& 704'35"E), coll Rajput; 1541, 1542, 1543 (The New College Herbarium! \& SUK!) 2016, MaharashtraKolhapur district, Ichalkaranji, coll. Kattee \& Shimpale; 1544, 1545 (The New College Herbarium! \& SUK!) 2016, Gadchiroli coll. Kattee \& Shimpale

\section{References}

Chowdhery, H.J. \& M.R. Debta (2009). A new species of Ipomoea L. (Convolvulaceae) from India. Indian Journal of Forestry 32(1): 119121.

Kattee, A.V., C.R. Patil, S.L. Patel, V.I. Kahalkar \& V.B. Shimpale (2019). Notes on the occurrence of Ipomoea acanthocarpa and Ipomoea laxiflora (Convolvulaceae) in India. Rheedea 29(3): 209-214.

Mabberley, D.J. (2017). The Plant-Book: A portable dictionary of plants, their classification and uses. Fourth edition. Cambridge University Press, Cambridge, 466-467 pp.

Meira, M., da E.P. Silva, J.P. David \& J.M. David (2012). Review of Genus /pomoea: Traditional uses, chemistry and biological activities. Revista Brasileira de Farmacognosia 22(3): 682-713.

Shimpale, V.B., M.A. Kare, D.K. Londhe \& A.S. Bhuktar (2014). On the occurrence of Ipomoea tenuipes (Convolvulaceae) in India. Rheedea 24(2): 117-119.

Singh, A.K., R.K. Sahu \& M. Srivastava (2011). On the occurrence of Ipomoea laxiflora in Uttar Pradesh. Indian Journal of Forestry 34(3): 335-338.

Singh, P., K. Karthigeyan, P. Lakshminarasimhan \& S.S. Dash (2015). Endemic Vascular Plants of India. Botanical Survey of India, Kolkata. 
Dr. John Noyes, Natural History Museum, London, UK

Dr. Albert G. Orr, Griffith University, Nathan, Australia

Dr. Sameer Padhye, Katholieke Universiteit Leuven, Belgium

Dr. Nancy van der Poorten, Toronto, Canada

Dr. Kareen Schnabel, NIWA, Wellington, New Zealand

Dr. R.M. Sharma, (Retd.) Scientist, Zoological Survey of India, Pune, India

Dr. Manju Siliwal, WILD, Coimbatore, Tamil Nadu, India

Dr. G.P. Sinha, Botanical Survey of India, Allahabad, India

Dr. K.A. Subramanian, Zoological Survey of India, New Alipore, Kolkata, India

Dr. P.M. Sureshan, Zoological Survey of India, Kozhikode, Kerala, India

Dr. R. Varatharajan, Manipur University, Imphal, Manipur, India

Dr. Eduard Vives, Museu de Ciències Naturals de Barcelona, Terrassa, Spain

Dr. James Young, Hong Kong Lepidopterists' Society, Hong Kong

Dr. R. Sundararaj, Institute of Wood Science \& Technology, Bengaluru, India

Dr. M. Nithyanandan, Environmental Department, La Ala Al Kuwait Real Estate. Co. K.S.C.,

Kuwait

Dr. Himender Bharti, Punjabi University, Punjab, India

Mr. Purnendu Roy, London, UK

Dr. Saito Motoki, The Butterfly Society of Japan, Tokyo, Japan

Dr. Sanjay Sondhi, TITLI TRUST, Kalpavriksh, Dehradun, India

Dr. Nguyen Thi Phuong Lien, Vietnam Academy of Science and Technology, Hanoi, Vietnam

Dr. Nitin Kulkarni, Tropical Research Institute, Jabalpur, India

Dr. Robin Wen Jiang Ngiam, National Parks Board, Singapore

Dr. Lional Monod, Natural History Museum of Geneva, Genève, Switzerland.

Dr. Asheesh Shivam, Nehru Gram Bharti University, Allahabad, India

Dr. Rosana Moreira da Rocha, Universidade Federal do Paraná, Curitiba, Brasi

Dr. Kurt R. Arnold, North Dakota State University, Saxony, Germany

Dr. James M. Carpenter, American Museum of Natural History, New York, USA

Dr. David M. Claborn, Missouri State University, Springfield, USA

Dr. Kareen Schnabel, Marine Biologist, Wellington, New Zealand

Dr. Amazonas Chagas Júnior, Universidade Federal de Mato Grosso, Cuiabá, Brasil

Mr. Monsoon Jyoti Gogoi, Assam University, Silchar, Assam, India

Dr. Heo Chong Chin, Universiti Teknologi MARA (UiTM), Selangor, Malaysia

Dr. R.J. Shiel, University of Adelaide, SA 5005, Australia

Dr. Siddharth Kulkarni, The George Washington University, Washington, USA

Dr. Priyadarsanan Dharma Rajan, ATREE, Bengaluru, India

Dr. Phil Alderslade, CSIRO Marine And Atmospheric Research, Hobart, Australia

Dr. John E.N. Veron, Coral Reef Research, Townsville, Australia

Dr. Daniel Whitmore, State Museum of Natural History Stuttgart, Rosenstein, Germany.

Dr. Yu-Feng Hsu, National Taiwan Normal University, Taipei City, Taiwan

Dr. Keith V. Wolfe, Antioch, California, USA

Dr. Siddharth Kulkarni, The Hormiga Lab, The George Washington University, Washington,

D.C., USA

Dr. Tomas Ditrich, Faculty of Education, University of South Bohemia in Ceske

Budejovice, Czech Republic

Dr. Mihaly Foldvari, Natural History Museum, University of Oslo, Norway

Dr. V.P. Uniyal, Wildlife Institute of India, Dehradun, Uttarakhand 248001, India

Dr. John T.D. Caleb, Zoological Survey of India, Kolkata, West Bengal, India

Dr. Priyadarsanan Dharma Rajan, Ashoka Trust for Research in Ecology and the Environment

(ATREE), Royal Enclave, Bangalore, Karnataka, India

\section{Fishes}

Dr. Neelesh Dahanukar, IISER, Pune, Maharashtra, India

Dr. Topiltzin Contreras MacBeath, Universidad Autónoma del estado de Morelos, México

Dr. Heok Hee Ng, National University of Singapore, Science Drive, Singapore

Dr. Rajeev Raghavan, St. Albert's College, Kochi, Kerala, India

Dr. Robert D. Sluka, Chiltern Gateway Project, A Rocha UK, Southall, Middlesex, UK

Dr. E. Vivekanandan, Central Marine Fisheries Research Institute, Chennai, India

Dr. Davor Zanella, University of Zagreb, Zagreb, Croatia

Dr. A. Biju Kumar, University of Kerala, Thiruvananthapuram, Kerala, India

Dr. Akhilesh K.V., ICAR-Central Marine Fisheries Research Institute, Mumbai Research

Centre, Mumbai, Maharashtra, India

Dr. J.A. Johnson, Wildlife Institute of India, Dehradun, Uttarakhand, India

Amphibians

Dr. Sushil K. Dutta, Indian Institute of Science, Bengaluru, Karnataka, India

Dr. Annemarie Ohler, Muséum national d'Histoire naturelle, Paris, France

\section{Reptiles}

Dr. Gernot Vogel, Heidelberg, Germany

Dr. Raju Vyas, Vadodara, Gujarat, India

Dr. Pritpal S. Soorae, Environment Agency, Abu Dubai, UAE.

Prof. Dr. Wayne J. Fuller, Near East University, Mersin, Turkey

Prof. Chandrashekher U. Rivonker, Goa University, Taleigao Plateau, Goa. India

Dr. S.R. Ganesh, Chennai Snake Park, Chennai, Tamil Nadu, India

Dr. Himansu Sekhar Das, Terrestrial \& Marine Biodiversity, Abu Dhabi, UAE
Birds

Dr. Hem Sagar Baral, Charles Sturt University, NSW Australia

Dr. Chris Bowden, Royal Society for the Protection of Birds, Sandy, UK

Dr. Priya Davidar, Pondicherry University, Kalapet, Puducherry, India

Dr. J.W. Duckworth, IUCN SSC, Bath, UK

Dr. Rajah Jayapal, SACON, Coimbatore, Tamil Nadu, India

Dr. Rajiv S. Kalsi, M.L.N. College, Yamuna Nagar, Haryana, India

Dr. V. Santharam, Rishi Valley Education Centre, Chittoor Dt., Andhra Pradesh, India

Dr. S. Balachandran, Bombay Natural History Society, Mumbai, India

Mr. J. Praveen, Bengaluru, India

Dr. C. Srinivasulu, Osmania University, Hyderabad, India

Dr. K.S. Gopi Sundar, International Crane Foundation, Baraboo, USA

Dr. Gombobaatar Sundev, Professor of Ornithology, Ulaanbaatar, Mongolia

Prof. Reuven Yosef, International Birding \& Research Centre, Eilat, Israel

Dr. Taej Mundkur, Wetlands International, Wageningen, The Netherlands

Dr. Carol Inskipp, Bishop Auckland Co., Durham, UK

Dr. Tim Inskipp, Bishop Auckland Co, Durham, UK

Dr. V. Gokula, National College, Tiruchirappalli, Tamil Nadu, India

Dr. Arkady Lelej, Russian Academy of Sciences, Vladivostok, Russia

Dr. Simon Dowell, Science Director, Chester Zoo, UK

Dr. Mário Gabriel Santiago dos Santos, Universidade de Trás-os-Montes e Alto Douro,

Quinta de Prados, Vila Real, Portugal

Dr. Grant Connette, Smithsonian Institution, Royal, VA, USA

Dr. M. Zafar-ul Islam, Prince Saud Al Faisal Wildlife Research Center, Taif, Saudi Arabia

Mammals

Dr. Giovanni Amori, CNR - Institute of Ecosystem Studies, Rome, Italy

Dr. Anwaruddin Chowdhury, Guwahati, India

Dr. David Mallon, Zoological Society of London, UK

Dr. Shomita Mukherjee, SACON, Coimbatore, Tamil Nadu, India

Dr. Angie Appel, Wild Cat Network, Germany

Dr. P.O. Nameer, Kerala Agricultural University, Thrissur, Kerala, India

Dr. Ian Redmond, UNEP Convention on Migratory Species, Lansdown, UK

Dr. Heidi S. Riddle, Riddle's Elephant and Wildlife Sanctuary, Arkansas, USA

Dr. Karin Schwartz, George Mason University, Fairfax, Virginia.

Dr. Lala A.K. Singh, Bhubaneswar, Orissa, India

Dr. Mewa Singh, Mysore University, Mysore, India

Dr. Paul Racey, University of Exeter, Devon, UK

Dr. Honnavalli N. Kumara, SACON, Anaikatty P.O., Coimbatore, Tamil Nadu, India

Dr. Nishith Dharaiya, HNG University, Patan, Gujarat, India

Dr. Spartaco Gippoliti, Socio Onorario Società Italiana per la Storia della Fauna "Giuseppe

Altobello", Rome, Italy

Dr. Justus Joshua, Green Future Foundation, Tiruchirapalli, Tamil Nadu, India

Dr. H. Raghuram, The American College, Madurai, Tamil Nadu, India

Dr. Paul Bates, Harison Institute, Kent, UK

Dr. Jim Sanderson, Small Wild Cat Conservation Foundation, Hartford, USA

Dr. Dan Challender, University of Kent, Canterbury, UK

Dr. David Mallon, Manchester Metropolitan University, Derbyshire, UK

Dr. Brian L. Cypher, California State University-Stanislaus, Bakersfield, CA

Dr. S.S. Talmale, Zoological Survey of India, Pune, Maharashtra, India

Prof. Karan Bahadur Shah, Budhanilakantha Municipality, Kathmandu, Nepal

Dr. Susan Cheyne, Borneo Nature Foundation International, Palangkaraja, Indonesia

Dr. Hemanta Kafley, Wildlife Sciences, Tarleton State University, Texas, USA

\section{Other Disciplines}

Dr. Aniruddha Belsare, Columbia MO 65203, USA (Veterinary)

Dr. Mandar S. Paingankar, University of Pune, Pune, Maharashtra, India (Molecular)

Dr. Jack Tordoff, Critical Ecosystem Partnership Fund, Arlington, USA (Communities)

Dr. Ulrike Streicher, University of Oregon, Eugene, USA (Veterinary)

Dr. Hari Balasubramanian, EcoAdvisors, Nova Scotia, Canada (Communities)

Dr. Rayanna Hellem Santos Bezerra, Universidade Federal de Sergipe, São Cristóvão, Brazil

Dr. Jamie R. Wood, Landcare Research, Canterbury, New Zealand

Dr. Wendy Collinson-Jonker, Endangered Wildlife Trust, Gauteng, South Africa

Dr. Rajeshkumar G. Jani, Anand Agricultural University, Anand, Gujarat, India

Dr. O.N. Tiwari, Senior Scientist, ICAR-Indian Agricultural Research Institute (IARI), New

Delhi, India

Dr. L.D. Singla, Guru Angad Dev Veterinary and Animal Sciences University, Ludhiana, India

Dr. Rupika S. Rajakaruna, University of Peradeniya, Peradeniya, Sri Lanka

Dr. Bahar Baviskar, Wild-CER, Nagpur, Maharashtra 440013, India

Reviewers 2018-2020

Due to pausity of space, the list of reviewers for $2018-2020$ is available online.

The opinions expressed by the authors do not reflect the views of the Journal of Threatened Taxa, Wildlife Information Liaison Development Society, Zoo Outreach Organization, or any of the partners. The journal, the publisher, the host, and the partners are not responsible for the accuracy of the political boundaries shown in the maps by the authors.

Journal of Threatened Taxa is indexed/abstracted in Bibliography of Systematic Mycology, Biological Abstracts, BIOSIS Previews, CAB Abstracts, EBSCO, Google Scholar, Index Copernicus, Index Fungorum, JournalSeek, National Academy of Agricultural Sciences, NewJour, OCLC WorldCat, SCOPUS, Stanford University Libraries, Virtual Library of Biology, Zoological Records.

NAAS rating (India) 5.64
Print copies of the Journal are available at cost. Write to:

The Managing Editor, JoTT,

c/o Wildlife Information Liaison Development Society,

No. 12, Thiruvannamalai Nagar, Saravanampatti - Kalapatti Road,

Saravanampatti, Coimbatore, Tamil Nadu 641035, India

ravi@threatenedtaxa.org 


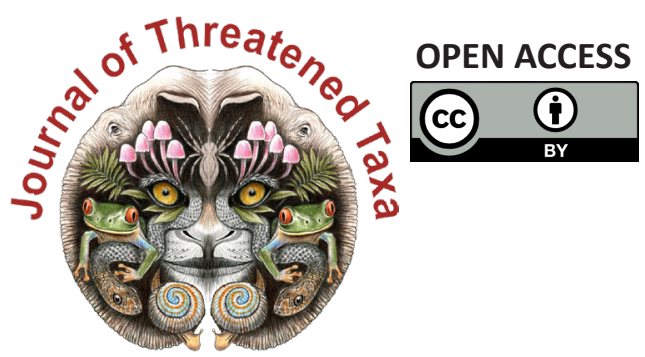

www.threatenedtaxa.org

The Journal of Threatened Taxa (JoTT) is dedicated to building evidence for conservation globally by publishing peer-reviewed articles online every month at a reasonably rapid rate at www.threatenedtaxa.org. All articles published in JoTT are registered under Creative Commons Attribution 4.0 International License unless otherwise mentioned. JoTT allows allows unrestricted use, reproduction, and distribution of articles in any medium by providing adequate credit to the author(s) and the source of publication.

\section{ISSN $0974-7907$ (Online) | ISSN $0974-7893$ (Print)}

\section{January 2022 | Vol. 14 | No. 1 | Pages: 20311-20538 \\ Date of Publication: 26 January 2022 (Online \& Print) DOI: 10.11609/jott.2022.14.1.20311-20538}

Articles

Estimating the completeness of orchid checklists and atlases: a case study from southern Italy

- Antonio Croce, Pp. 20311-20322

A floristic survey across three coniferous forests of Kashmir Himalaya, India - a checklist

- Ashaq Ahmad Dar, Akhtar Hussain Malik \& Narayanaswamy Parthasarathy, Pp. 20323-20345

Associations of butterflies across different forest types in Uttarakhand, western Himalaya, India: implications for conservation planning

- Arun Pratap Singh, Pp. 20346-20370

Comparison of bird diversity in protected and non-protected wetlands of western lowland of Nepal

- Jagan Nath Adhikari, Janak Raj Khatiwada, Dipendra Adhikari, Suman Sapkota, Bishnu Prasad Bhattarai, Deepak Rijal \& Lila Nath Sharma, Pp. 20371-20386

Local hunting practices and perceptions regarding the distribution and ecological role of the Large Flying Fox (Chiroptera: Pteropodidae: Pteropus vampyrus) in western Sarawak, Malaysian Borneo

- Jayasilan Mohd-Azlan, Joon Yee Yong, Nabila Norshuhadah Mohd Hazzrol, Philovenny Pengiran, Arianti Atong \& Sheema Abdul Aziz, Pp. 20387-20399

\section{Communications}

Macrolichens of Mathikettan Shola National Park, Western Ghats: a preliminary investigation with some new records

- Aswathi Anilkumar, Stephen Sequeira, Arun Christy \& S.M. Arsha, Pp. 20400-20405

New distribution record of globally threatened Ocean Turf Grass Halophila beccarii Ascherson, 1871 from the North Andaman Islands highlights the importance of seagrass exploratory surveys

- Swapnali Gole, Prasad Gaidhani, Srabani Bose, Anant Pande, Jeyaraj Antony Johnson \& Kuppusamy Sivakumar, Pp. 20406-20412

An inventory of new orchid (Orchidaceae) records from Kozhikode, Kerala, India - M. Sulaiman, C. Murugan \& M.U. Sharief, Pp. 20413-20425

Abundance and spatial distribution analyses of Stemonoporus moonii Thwaites (Dipterocarpaceae) - a critically endangered species endemic to Sri Lanka - K.A.M.R.P. Atapattu, H.D.D.C.K. Perera, H.S. Kathriarachchi \& A.R. Gunawardena, Pp. 20426-20432

Plant diversity of Point Calimere Wildlife Sanctuary and fodder species grazed by the Blackbuck Antilope cervicapra L.

- Ashutosh Kumar Upadhyay, A. Andrew Emmanuel, Ansa Sarah Varghese \&

D. Narasimhan, Pp. 20433-20443

Raptors observed (1983-2016) in National Chambal Gharial Sanctuary: semi-arid biogeographic region suggestions for parametric studies on ecological continuity in Khathiar-Gir Ecoregion, India

- L.A.K. Singh, R.K. Sharma \& Udayan Rao Pawar, Pp. 20444-20460

Nesting success of Sharpe's Longclaw (Macronyx sharpei Jackson, 1904) around the grasslands of lake Ol'bolossat Nyandarua, Kenya

- Hamisi Ann Risper, Charles M. Warui \& Peter Njoroge, Pp. 20461-20468

Population, distribution and diet composition of Smooth-coated Otter Lutrogale perspicillata Geoffroy, 1826 in Hosur and Dharmapuri Forest Divisions, India - Nagarajan Baskaran, Raman Sivaraj Sundarraj \& Raveendranathanpillai Sanil, Pp. 20469-20477

Utilization of home garden crops by primates and current status of human-primate interface at Galigamuwa Divisional Secretariat Division in Kegalle District, Sri Lanka

- Charmalie Anuradhie Dona Nahallage, Dahanakge Ayesha Madushani Dasanayake, Dilan Thisaru Hewamanna \& Dissanayakalage Tharaka Harshani Ananda, Pp. 2047820487
Revival of Eastern Swamp Deer Rucervus duvaucelii ranjitsinhi (Groves, 1982) in Manas National Park of Assam, India

- Nazrul Islam, Aftab Ahmed, Rathin Barman, Sanatan Deka, Bhaskar Choudhury, Prasanta Kumar Saikia \& Jyotishman Deka, Pp. 20488-20493

Trypanosoma evansi infection in a captive Indian Wolf Canis lupus pallipes - molecular diagnosis and therapy

- Manojita Dash, Sarat Kumar Sahu, Santosh Kumar Gupta, Niranjana Sahoo \& Debarat Mohapatra, Pp. 20494-20499

View Point

COVID-19 and civil unrest undoing steady gains in karst conservation and herpetological research in Myanmar, and an impediment to progress - Evan S.H. Quah, Lee L. Grismer, Perry L. Wood, Jr., Aung Lin \& Myint Kyaw Thura, Pp. 20500-20502

\section{Short Communications}

Morphological characterization and mt DNA barcode of a tiger moth species, Asota ficus (Fabricius, 1775) (Lepidoptera: Noctuoidea: Erebidae: Aganainae) from India - Aparna Sureshchandra Kalawate, K.P. Dinesh \& A. Shabnam, Pp. 20503-20510

Distribution of Smooth-coated Otters Lutrogale perspicillata (Mammalia: Carnivora: Mustelidae): in Ratnagiri, Maharashtra, India

- Swanand Patil \& Kranti Yardi, Pp. 20511-20516

Wildlife at the crossroads: wild animal road kills due to vehicular collision on a mountainous highway in northwestern Himalayan region

- Muzaffar A. Kichloo, Asha Sohil \& Neeraj Sharma, Pp. 20517-20522

Notes

Robiquetia gracilis (Lindl.) Garay-a new record to the flora of Anamalai Hills, Tami Nadu, India

- B. Subbaiyan, V. Ganesan, P.R. Nimal Kumar \& S. Thangaraj Panneerselvam, Pp. 20523-20525

Ipomoea laxiflora H.J. Chowdhery \& Debta (Convolvulaceae): new records for the Western Ghats and semiarid regions

- Sachin M. Patil, Ajit M. Vasava, Vinay M. Raole \& Kishore S. Rajput, Pp. 20526-20529

Counting the cost: high demand puts Bunium persicum (Boiss.) B.Fedtsch. in jeopardy

- Monika Sharma, Manisha Mathela, Rupali Sharma, Himanshu Bargali, Gurinderjit S Goraya \& Amit Kumar, Pp. 20530-20533

First record of Parasitic Jaeger Stercorarius parasiticus (Aves: Charadriiformes: Stercorariidae) from inland freshwater Inle Lake, Myanmar

- Sai Sein Lin Oo, Myint Kyaw, L.C.K. Yun, Min Zaw Tun, Yar Zar Lay Naung, Soe Naing Aye \& Swen C. Renner, Pp. 20534-20536

\section{Book Review}

Capparis of India

- V. Sampath Kumar, Pp. 20537-20538
Publisher \& Host
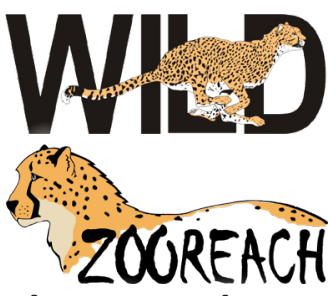

Threatened Taxa 